\title{
Strategies to Overcome Constraints in Adoption of Improved Paddy Cultivation Practices in Navsari and Surat District of South Gujarat, India
}

\author{
M.B. Tengli ${ }^{*}$ and O.P. Sharma ${ }^{2}$ \\ ${ }^{1}$ Division of Dairy Extension, ICAR-NDRI, Karnal, 132001, Haryana, India \\ ${ }^{2}$ Department of Agricultural Extension, NMCA, NAU, Navsari, 396450, Gujarat, India \\ *Corresponding author
}

\section{A B S T R A C T}

\begin{tabular}{|l|}
\hline Ke y w o r d s \\
Adoption, Constraints, \\
$\begin{array}{l}\text { Hoarding, Paddy } \\
\text { cultivation practices, } \\
\text { Strategies and } \\
\text { Suggestions. }\end{array}$ \\
\hline Article Info \\
\hline $\begin{array}{l}\text { Accepted: } \\
\text { 10 September } 2017 \\
\text { Available Online: } \\
\text { 10 November } 2017\end{array}$ \\
\hline
\end{tabular}

\section{Introduction}

Agriculture is the mainstay of India's food security and rural economic security, which for centuries has shaped the culture of its human resource. More than 72.20 per cent of India's population is living in villages and majority of them are engaged in agricultural enterprise. Agriculture sector employs 54.60 per cent of the total workforce (Anonymous, 2014). Rice (Oryza sativa L.) is considered as a first cultivated crop of Asia. More than 90.00 per cent of the world's rice is grown and consumed in Asia, where 60.00 per cent of the world's population lives. Rice accounts for 35.00 per cent to 60.00 per cent of the caloric intake of three billion Asians. Over 150 million hectares of rice is planted annually, covering about 10.00 per cent of the world's arable land, thus rice is the most important staple food in Asia. With the world population estimated to increase from 7.00 billion in the year 2014 to about 8.2 billion in the year 2030, the global rice demand will rise to about 765 million tonnes, or 533 million tonnes of milled rice (FAO, 2014). Since the 
Green Revolution, the rice yield growth rate was approximately 2.5 per cent per year this has decreased to 1.1 per cent (Riveros and Figures, 2000). In respect of production, India ranks second with 154.6 million tonnes of paddy (103.6 million tonnes, milled basis) next to China (206.4 million tonnes of paddy, 144.4 million tonnes on milled basis), (FAO, 2015). As far as average yield per hectare is concerned, Korea Republic ranks first (5200 $\mathrm{kg} / \mathrm{ha}$ ) and that of India is only $2424 \mathrm{~kg} / \mathrm{ha}$ (Anonymous, 2014a). Rice, besides being a major source of dietary energy, constitutes a natural medicine used mainly as a popular remedy. Gujarat State rice occupies about 7.00 to 8.00 per cent of the gross cropped area of the country and accounts for around 14.00 per cent of the total food grain production. It is observed from the yield of paddy, the average yield at national level is $2424 \mathrm{~kg}$ per hectare and the average yield of rice of Gujarat state is $1500-1800 \mathrm{~kg}$ per hectare. Similarly, the average yield in the districts under study Navsari and Surat is $3600 \mathrm{~kg}$ per hectare and $3650 \mathrm{~kg}$ per hectare respectively. The yield of selected Navsari district is higher than the national and state average yield and also it is higher than the potential yield 1500$1800 \mathrm{~kg}$ per hectare. To reach the fullest yield potential adoption of improved technology is central. Technology adoption is as important as its availability, various factors influence the adoption. Thus lower level of adoption is reported. Majority of paddy growers' adoption level was medium (Sasane et al., 2012). Even the beneficiaries of certain programmes reported to have medium level of adoption of paddy production technology (Dholariya et al., (2015). It is indicative of certain constraints hindering our farmers in adopting technologies. Various researchers reported constraints faced by farmers in adoption of paddy cultivation practices (Shanmugasundaram and Helen, 2015; Gopal et al., 2014; Thorat et al., 2012). Strategies refer to long-term plan which involve the future course of actions to be taken and allocation of resources to achieve the intended goal. With this premise the above study was undertaken with following specific objectives,

To elicit the constraints as perceived by the paddy growers in adoption of improved paddy cultivation practices

To suggest the future strategies to overcome the constraints in adoption of improved paddy cultivation practices

\section{Materials and Methods}

Ex-post-facto research design was used in the present investigation. South Gujarat comprises of seven sister districts, out of these Navsari and Surat districts were selected following purposive sampling method, as these Navsari (3600 kg/ha. Anonymous, 2014a) and Surat (3650 kg/ha. Anonymous, 2014b) districts have highest productivity among all the seven districts of South Gujarat region. Both the study area are blessed with suitable climate and other natural resources for cultivation of paddy. Following simple ransom sampling procedure two taluka from each selected districts, five villages from each taluka and 10 respondent paddy growers from each selected village were selected making a total of 100 respondents.

To know the constraints faced by the farmers in adoption of improved/recommended cultivation practices of paddy, they were asked to state the problems and were recorded accordingly. Obtained problems were expressed in terms of frequency and percentage. Respondents were asked to provide suggestion against the constraints and obtained suggestions were expressed in terms of frequency and percentage. The opinion of technical experts on constraints and suggestions offered by the respondent paddy growers was screen out separately and 
triangulation method was used to propose the strategy to overcome major constraints on priority basis.

\section{Results and Discussion}

\section{Socio-economic profile of the respondents}

Socio-economic status of the respondents is an important and integral part of any social science research. The profile study reveals that, half of the respondents $(50.00 \%)$ belonged to middle age category, majority of the respondents $(58.00 \%)$ had education up to the secondary level of education, 90.00 percent respondents were having medium (6 to 15 years) to high level (Above 15 years) of farming experience, 54.00 percent of them had medium ( 2 to 5 Acres) land holding, with 61.00 percent belonging to low income category (Rs. 50,001/- to $1,00,000 /$-), more than 70.00 percent respondents belonged to medium categories in following variables, material possession (70.00\%), mass media exposure $(73.00 \%)$, risk orientation $(80.00$ $\%)$, social participation $(77.00 \%) .55 .00$ percent, 53.00 percent and 44.00 percent of respondents belonged to medium categories of scientific orientation, extension contact and extension participation, respectively.

Constraints as perceived by the paddy growers in adoption of improved paddy cultivation practices

Constraints refer to hindrance or obstruction or problems faced by paddy growers in adoption of improved/recommended paddy cultivation practices.

The data presented in table 1 indicates that the 98.00 per cent of the respondent paddy growers reported the constraint "Labour problem" and ranked at first position, followed by the constraint "High cost of inputs" and "Lower market price of produce", which was faced by 91.00 and 88.00 per cent respondent paddy growers and ranked at second and third position, respectively.

Furthermore, the constraint "Inadequate supply of quality inputs in time", " Lack of effective marketing system", "Complicated procedure to obtain crop loan", "Price fluctuation", "Inadequate irrigation facility", "Non availability of technical knowledge" and "Less number of demonstrations" were faced by 76.00 per cent, 74.00 per cent, 69.00 per cent, 67.00 per cent, 57.00 per cent, 55.00 per cent and 46.00 per cent of the respondent paddy growers and therefore ranked at fourth, fifth, sixth, seventh, eighth, ninth and tenth position, respectively.

Suggestions expressed by the paddy growers to counteract the constraints in adoption of improved paddy cultivation practices

Suggestions are the probable solution or ways or opinions to overcome the constraints as expressed by the paddy growers.

The data presented in table 2 indicates that the 82.00 per cent of the respondent paddy growers expressed the suggestion "Provide financial support for purchasing of farm machinery" and ranked at first position, followed by the suggestions "Generic agriculture stores should be formed where quality inputs are sold at higher subsidized price" and "Provide storage facility for harnessing advantage of hedging", which was faced by 80.00 and 78.00 per cent respondent paddy growers and ranked at second and third position, respectively.

Furthermore, the suggestions "Form a system for supply chain for timely availability of inputs", "Provide adequate marketing information", "Provide adequate information regarding crop loans", "Provide marketing 
management information", "Canal should be made in unreached areas", "Organize extension activates at village level" and "Conduct demonstrations in different panchayat in rotation" were faced by 64.00 per cent, 62.00 per cent, 60.00 per cent, 58.00 per cent, 56.00 per cent, 51.00 per cent and 43.00 per cent of the respondent paddy growers and therefore ranked at fourth, fifth, sixth, seventh, eighth, ninth and tenth position, respectively.

Table 3 indicates the major constraints, suggestions, experts' opinion, the proposed strategy and the executing agency.
Strategies to overcome the constraints in adoption of improved paddy cultivation practices

The proposed strategy based on the constraints and experts suggestions are as follows,

To resolve the labour problem farmers should collectively help each other with their available resources by forming Commodity Interest Group (CIG) under Agricultural technology Management Agency (ATMA), the CIG formation and collective utilization of resources should be executed by ATMA.

Table.1 Distribution of respondents according to constraints faced by them in the adoption of improved paddy cultivation practices

\begin{tabular}{|l|l|c|c|c|}
\hline Sr. & Constraints & Frequency & Percentage & Rank \\
\hline 1. & Labour problem & 98 & 98.00 & I \\
\hline 2. & High cost of inputs & 91 & 91.00 & II \\
\hline 3. & Lower market price of produce & 88 & 88.00 & III \\
\hline 4. & Inadequate supply of quality inputs in time & 76 & 76.00 & IV \\
\hline 5. & Lack of effective marketing information & 74 & 74.00 & V \\
\hline 6. & Lack of information regarding crop loans & 69 & 69.00 & VI \\
\hline 7. & Price fluctuation & 67 & 67.00 & VII \\
\hline 8. & Inadequate irrigation facility & 57 & 57.00 & VIII \\
\hline 9. & Non availability of technical knowledge & 55 & 55.00 & IX \\
\hline 10. & Less number of demonstrations & 46 & 46.00 & X \\
\hline
\end{tabular}

Table.2 Distribution of respondents according the ranked suggestions

\begin{tabular}{|c|l|c|c|c|}
\hline \multicolumn{2}{|c|}{$(\mathrm{n}=100)$} \\
\hline Sr. & Suggestions & F & \% & Rank \\
\hline 1. & Provide financial support for purchasing of farm machinery & 82 & 82.00 & I \\
\hline 2. & $\begin{array}{l}\text { Generic agriculture stores should be formed where quality inputs } \\
\text { are sold at higher subsidized price }\end{array}$ & 80 & 80.00 & II \\
\hline 3. & Provide storage facility for harnessing advantage of hoarding & 78 & 78.00 & III \\
\hline 4. & Form a system for supply chain for timely availability of inputs & 64 & 64.00 & IV \\
\hline 5. & Provide adequate marketing information & 62 & 62.00 & V \\
\hline 6. & Provide adequate information regarding crop loans & 60 & 60.00 & VI \\
\hline 7. & Provide marketing management information & 58 & 58.00 & VII \\
\hline 8. & Canal should be made in unreached areas & 56 & 56.00 & VIII \\
\hline 9. & Organize extension activates at village level & 51 & 51.00 & IX \\
\hline 10. & Conduct demonstrations in different panchayat in rotation & 43 & 43.00 & X \\
\hline & F-Frequency and \%- Percentage & & \\
\hline
\end{tabular}


Table.3 Proposed strategy to overcome the constraints

\begin{tabular}{|c|c|c|c|c|c|}
\hline Sr. & Constraints & $\begin{array}{l}\text { Suggestion from } \\
\text { paddy growers }\end{array}$ & $\begin{array}{l}\text { Options of } \\
\text { Experts }\end{array}$ & $\begin{array}{c}\text { Proposed } \\
\text { strategy based } \\
\text { on } \\
\text { triangulation }\end{array}$ & Who will execute \\
\hline 1 & 2 & 3 & 4 & 5 & 6 \\
\hline 1. & $\begin{array}{l}\text { Labor } \\
\text { problem }\end{array}$ & $\begin{array}{l}\text { Provide financial } \\
\text { support for } \\
\text { purchasing of farm } \\
\text { machinery }\end{array}$ & $\begin{array}{l}\text { Farmers should } \\
\text { collectively } \\
\text { help each other } \\
\text { with their } \\
\text { available } \\
\text { resources }\end{array}$ & $\begin{array}{l}\text { Form the } \\
\text { Commodity } \\
\text { Interest Group } \\
\text { under ATMA }\end{array}$ & ATMA \\
\hline 2. & $\begin{array}{l}\text { High cost of } \\
\text { inputs }\end{array}$ & $\begin{array}{l}\text { Generic agriculture } \\
\text { stores should be } \\
\text { formed where } \\
\text { quality inputs are } \\
\text { sold at higher } \\
\text { subsidized price }\end{array}$ & $\begin{array}{l}\text { ATIC should be } \\
\text { approach }\end{array}$ & $\begin{array}{l}\text { Approach the } \\
\text { ATIC, Navsari }\end{array}$ & $\begin{array}{c}\text { ATIC, } \\
\text { NAU Navsari }\end{array}$ \\
\hline 3. & $\begin{array}{c}\text { Lower } \\
\text { market price } \\
\text { of produce }\end{array}$ & $\begin{array}{c}\text { Provide storage } \\
\text { facility for } \\
\text { harnessing } \\
\text { advantage of } \\
\text { hoarding } \\
\end{array}$ & $\begin{array}{l}\text { Use APMC } \\
\text { warehouse }\end{array}$ & $\begin{array}{l}\text { Approach } \\
\text { APMC in the } \\
\text { district }\end{array}$ & APMC \\
\hline 4. & $\begin{array}{l}\text { Inadequate } \\
\text { supply of } \\
\text { quality inputs } \\
\text { in time }\end{array}$ & $\begin{array}{c}\text { Form a system for } \\
\text { supply chain for } \\
\text { timely availability of } \\
\text { inputs }\end{array}$ & $\begin{array}{c}\text { Planning should } \\
\text { be made in } \\
\text { advance }\end{array}$ & $\begin{array}{l}\text { Approach the } \\
\text { ATIC, Navsari }\end{array}$ & $\begin{array}{c}\text { ATIC, } \\
\text { NAU Navsari }\end{array}$ \\
\hline 5. & $\begin{array}{c}\text { Lack of } \\
\text { effective } \\
\text { marketing } \\
\text { information }\end{array}$ & $\begin{array}{l}\text { Provide adequate } \\
\text { marketing } \\
\text { information }\end{array}$ & $\begin{array}{l}\text { Contact KVK } \\
\text { for ICT } \\
\text { initiative in } \\
\text { marketing }\end{array}$ & $\begin{array}{c}\text { Approach } \\
\text { nearby KVK }\end{array}$ & $\begin{array}{c}\text { KVK, Navsari } \\
\text { NAU }\end{array}$ \\
\hline 6. & $\begin{array}{l}\text { Lack of } \\
\text { information } \\
\text { regarding } \\
\text { crop loans }\end{array}$ & $\begin{array}{l}\text { Provide adequate } \\
\text { information } \\
\text { regarding crop loans }\end{array}$ & $\begin{array}{l}\text { Contact RRB, } \\
\text { Cooperative } \\
\text { banks }\end{array}$ & $\begin{array}{c}\text { Approach } \\
\text { nearby RRB }\end{array}$ & $\begin{array}{l}\text { RRB and } \\
\text { Cooperative } \\
\text { banks }\end{array}$ \\
\hline
\end{tabular}

To reduce high cost of inputs Agricultural Technology Information Centre (ATIC) should be approached for purchase of low cost inputs, the supply of low cost inputs should be made available by ATIC.

To avoid lower market price of produce the advantage of hedging can be taken by storing the produce in Agriculture Produce Marketing Corporation (APMC) warehouses, sufficient and safe storage facility must be provided by the district APMC.

To avoid inadequate supply of quality inputs in time approach ATIC for planning the input purchase well in advance and the ATIC should make available quality and adequate quantity inputs in time to farmers.

To harness market information farmers can make use of ICT initiatives of Krishi Vigyan 
Kendra (KVK) by approaching nearby KVK.

To get complete information regarding crop loans farmers are advised to approach Regional Rural Bank (RRB) and the RRBs; must provide all possible assistance to farmers in easy access to crop loans.

From the aforementioned findings it can be concluded that majority of the respondent paddy growers reported the constraint "Labour problem" followed by the constraint "High cost of inputs" and "Lower market price of produce", on contrary to constraints the suggestions were "Provide financial support for purchasing of farm machinery" followed by the suggestions "Generic agriculture stores should be formed where quality inputs are sold at higher subsidized price" and "Provide storage facility for harnessing advantage of hedging". The proposed strategies must be implemented effectively by the implementing agencies for counteracting the constraints faced by the paddy growers in adoption of improved paddy cultivation practices.

\section{References}

Anonymous. 2014a. Annual report 2013-2014. Department of Agriculture and Cooperation, Government of India.p.2-5.

Anonymous. 2014b. Annual Progress Report 2013-14. Krishi Vigyan Kendra, Navsari. p.9 10.

Anonymous. 2014c. Annual Progress Report 2013-14. Krishi Vigyan Kendra, Surat. p.9.

Dholariya, P. C., V. P. Vejpara, Parmar, V. S. and Bhuva, R. M. 2015. Extent of Adoption of Beneficiaries of FLDS and Non- Beneficiaries about Paddy
Production Technology. VII National Seminar of Society for Community Mobilization for Sustainable Development on Sustainable Rural Livelihood: Technological \& Institutional Perspective, Souvenir-Abstracts, 4.3.p130.

Food and Agriculture Organization. 2014. Rice market monitor, report 17(1): 1-5.

Food and Agriculture Organization. 2015. Rice market monitor, report 18(2): 2-6.

Gopal, P. V., K. Sreedevi and Prasad, S. V. 2014. Constraint analysis of integrated pest management (IPM) in rice and the strategies to overcome the constraints. Current Biotica, 7(4): 306-313.

Riveros, F. and Figures, P. 2000. Keynote address of the 18th session of IRC Nanda JS. Rice Breeding and Genetics: Research Priorities and Challenges. Rice Breeding and Genetics, Research Priorities and Challenges, Science Publishers Inc. pp. 18.

Sasane, K. L., P. A Patil and Suthar, P. P. 2012. Knowledge and adoption of Paddy cultivation practices among farmers in north Kashmir. Asian Journal of. Extension. Education, xxiii (2): 46:51.

Shanmugasundaram and Helen. 2015. Adoption of System of Rice Intensification under Farmer Participatory Action Research Programme (FPARP). Indian Research Journal of Extension Education, 15 (1): 114-117.

Thorat, K. S., D. B. Suryawanshi and Ban, S. H. 2012. Technological Gap in Adoption of Recommended Cultivation Practices of Mango Growers and Constraints Faced by Them. Mysore Journal of Agricultural Sciences, 46 (1): 160-163.

\section{How to cite this article:}

Tengli, M.B. and Sharma, O.P. 2017. Strategies to Overcome Constraints in Adoption of Improved Paddy Cultivation Practices in Navsari and Surat District of South Gujarat, India. Int.J.Curr.Microbiol.App.Sci. 6(11): 932-937. doi: https://doi.org/10.20546/ijcmas.2017.611.109 